INTERNATIONAL JOURNAL OF RESEARCHES IN BIOSCIENCES, AGRICULTURE AND TECHNOLOGY (C) VISHWASHANTI MULTIPURPOSE SOCIETY (Global Peace Multipurpose Society) R. No. MH-659/13(N) www.vmsindia.org

\title{
IMPACT OF NEUROHORMONES OF THE OPTIC TENTACLES ON THE POLYSACCHARIDE METABOLISM OF THE ALBUMEN GLAND OF SEMPERULA MACULATA
}

\author{
P. P. Yadav and S. G. Nanaware \\ Sm. Dr. Bapuji Salunkhe College,Miraj,Maharashtra,India. \\ pradip.yadav51@yahoo.com
}

\begin{abstract}
:
The effect of the extracts of the optic tentacles on the synthesis of polysaccharides in the albumen gland of the land slug S. maculata have been studied with help of histochemical tests.It was observed that the acini of the gland contained both the glycogen and galactogen polysaccharides. The hormones in the tentacles increased the synthesis of galactogen and decreased synthsis of the glycogen. The accumulation of galactogen in this gland seems to be utilized for the synthesis of perivitelline fluid around eggs and the glycogen utilized for the synthesis of galactogen.Such interconversion of polysaccharides was found useful in the gametogenesis and for the nutrition and survival of gametes of slugs.
\end{abstract}

Keywords: polysaccharides, optic tentacle, albumen gland, metabolism

\section{Introduction:}

In pulmonate mollusks, the albumen gland,which is one of the accessory sex organs[ASD], produces a secretion which acts as perivitelline fluid. The main reserves for the embryo are stored in the perivitellin flude[Goudsmit,1975]. This flud is rich in an unusual polysaccharide, galactogen, which is the characteristic polysaccharide species of pulmonate gastropods (Horstmann,1956;McMahon et al., 1957; Goudsmit and Ashwell,1965 and Goudsmit,1972.).The production of galactogen puts a high demand on the metabolism of other carbohydrates of these slugs.

Several studies have established the endocrine regulation of the synthesis of galactogen in the albumen gland either by the dorsal bodies [DBs]alone or by the DBs and the brain combined[Abeloos, 1943; Laviole by 1954; Runham et. Al., 1973; Goudsmit,1975; Wijdenes et. Al., 1983 and Miksys and Saleuddin, 1985, Yadav \& Nanaware et. Al., 2009.]. Since the DBs regulate synthetic activities of the albumen gland, here the attempt has been made to study the induction of galactogen synthesis in the albumen gland following the injection of extract of the optic tentacles.

\section{Material and Methods:}

For the present study the slugs were collected from the local gardens in July and August.They were transported immediately to the laboratory and were maintained in plastic troughs filled with soil which was from the same fields and they were fed with their natural food like cabbage canan leaves etc.The troughs were covered with mosquito curtain cloths and the soil was kept moist so as to provide their natural humidity. Water was always made available to the animals and they were fed daily in the evenings only. As they were kept at room temperature and on normal feeding, they prevented from winter hibernation.

\section{Preparation of homogenate:}

The optic tentacles of the S. maculata were cut and homogenate was prepared in the molluscan saline solution $[\mathrm{NaCl} 5.7 \mathrm{gm} /$ lit; Kcl0.15gm/lit;cacl2 1.11 gm/lit;pH 7.5 ].the extracts were ijected to the animals for 5 days[ $1 \mathrm{ml}$ to each slug every day].Afterwards the albumen glands were dissected out from the experimental animals after 10 th days, $20^{\text {th }}$ days ,30th days, $40^{\text {th }}$ days $\& 50^{\text {th }}$ days.the albumen gland of control animals and experimental animals were fixed for the histochemical and biochemical observations in the calcium formaline acetate $\quad[\mathrm{CAF}] \quad(10 \%$

formaldehyde containing $2 \%$ calcium acetate). The pieces of the glands were fixed for $24 \mathrm{hrs}$.After fixation the tissues in both the cases were well washed under running water following by routine processing for paraffin embedding and section at 5-7u.

\section{Histochemical Procedures:}

For the histochemical detection of glycogen and galactogen the section of albumen gland stained by PAS technique, malt diastase or saliva digestion-PAS, $\mathrm{AB}$ [PH 1.0], $\mathrm{AB}[\mathrm{PH} 2.5]$ and sequential staining techniques such as $\mathrm{AB}[\mathrm{PH}$ 1.0,2.5] -PAS, [Spicer et.al.,1957, varute and Nanaware, 1972].

\section{Biochemical Procedure:}

For the quantitative estimation of glycogen and galactogen colorimetric method of Caroll et. al., (1956) was used. 


\section{Results and Discussion:}

The polysaccharides glycogen and galactogen showed very different histochemical reactivities which have been summarized in Table No. 1 and biochemical per cent values of total polysaccharides, glycogen \& galactogen are compied in Table No.2.

The injection of the extracts of optic tentacles caused a steady increase in the galactogen during the experimental period.Neiland and Goudsmit[1969], reported that in the albumen gland of Helix pomatia both glycogen and galactogen can be demonstrated in the same type of cells. The polysaccharides contain glycogen and galactogen.But in the actively reproducing slugs, galactogen synthesis predominates since egg polysaccharide is known to be galactogen.

The secretion in the secretory cells of this slug shows intense-PAS reactivity. ThePAS reactivity of these granules was affected by the saliva digestion in the experimental animals. The globules showed slightly faint alcinophilia at $\mathrm{PH}$ 2.5 but reacted negatively at $\mathrm{PH} 1.0$ with Alcian blue. In the $\mathrm{AB}[\mathrm{PH} 1.0,2.5]-\mathrm{PAS}$ sequential staining procedures the globules stained intensely pink.

According to above histochemical observatoions nothing can be said, except for the fact that galactogen is secreted and used at egg laying period. The present literature clearly indicated that it mainly employed in the egg coat formation [Horstmann 1956].

Joosse et.al. [1968] investigated that in the fresh water species Lymnea stagnalis the production of galactogen put high demand on metabolism of these snails.According to them the egg mass was produced after every 2or 3 days and contained 2-5mg of galactogen when total glycogen reserves in the body was amounting $15-20 \mathrm{mg}$.

The normal values of total polysaccharides in the albumen gland ranged from $5.50 \mathrm{mg}$ to 8.14 mgper $100 \mathrm{mg}$ of wet tissue. The glycogen concentration ranged from $1.23 \mathrm{mg}$ to $2.50 \mathrm{mg}$ and that of galactogen from $3.00 \mathrm{mg}$ to $6.91 \mathrm{mg}$ per $100 \mathrm{mg}$ of wet tissue At a comparative level the concentration of polysaccharide, galactogen was higher than that of glycogen.

The injection of extract of the optic tentacles showed variations in the polysaccharide contents in the albumen gland. These variations were distinctly opposite in slugs with the tentacles and slugs with ablated tentacles.

The per cent values showing the changes in the total polysaccharides,glycogen \& galactogen are compiled in Table No. 2 and they are shown graphically in graph in which the polysaccharide contents have plotted as a function of days after injection of extracts of optic tentacles. To confirm effects of various experimental conditions created due to neuroendocrine secretions on the qualitative changes in the polysaccharides the biochemical studies were performed. The quantitative biochemical estimation of the total polysaccharides coincided with the histochemical qualitative results observed in the albumen gland.

Thus from results of the present investigation it seems that the galactogen synthesis in the albumen gland is under the control of neurosecretory hormones in the optic tentacles.

Table-1: Histochemical staining reactions of the galactogen in the albumen gland of S. Maculata.

\begin{tabular}{|c|c|c|c|c|c|c|c|c|c|c|c|c|c|}
\hline \multirow{5}{*}{$\begin{array}{l}\text { Sr } \\
\text { no. }\end{array}$} & \multirow{5}{*}{$\begin{array}{l}\text { Histochemical } \\
\text { Techniques }\end{array}$} & \multicolumn{12}{|c|}{ Histochemical Reactions } \\
\hline & & \multicolumn{6}{|c|}{ GLYCOGEN } & \multicolumn{6}{|c|}{ GALACTOGEN } \\
\hline & & \multirow[b]{3}{*}{ Control } & \multicolumn{5}{|c|}{ OTAB + OTEI } & \multirow{3}{*}{ Control } & \multicolumn{5}{|c|}{ OTIN + OTEI } \\
\hline & & & \multicolumn{5}{|c|}{ Exprimental Days } & & \multicolumn{5}{|c|}{ Exprimental Days } \\
\hline & & & 10 & 20 & 30 & 40 & 50 & & 10 & 20 & 30 & 40 & 50 \\
\hline 1. & $\mathrm{H}+\mathrm{E}$ & ++++ & ++++ & +++ & +++ & ++ & + & + & ++ & ++ & +++ & +++ & ++++ \\
\hline 2. & Mallory's Triple & ++++ & ++++ & +++ & +++ & ++ & + & + & ++ & ++ & +++ & +++ & ++++ \\
\hline 3. & PAS & +++++ & ++++ & +++ & +++ & ++ & + & + & ++ & ++ & +++ & +++ & 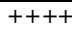 \\
\hline 4. & Maltdistase-PAS & +++++ & - & - & - & ++ & - & + & ++ & ++ & ++++ & ++++ & +++++ \\
\hline 5. & Saliva digestion -PAS & ++++ & - & - & - & - & + & + & ++ & ++ & +++ & +++ & +++++ \\
\hline 6. & $\mathrm{AB} \mathrm{pH} 1.0$ & - & - & - & - & - & - & - & - & - & - & - & - \\
\hline 7. & AB pH $1.0-\mathrm{PAS}$ & +++++ & +++++ & ++++ & +++ & ++ & & + & ++ & ++ & ++++ & +++ & +++++ \\
\hline 8. & AB pH 2.5 & - & - & - & - & - & - & - & - & - & - & - & - \\
\hline 9. & $\mathrm{AB}$ pH $2.5-\mathrm{PAS}$ & ++++ & ++++ & ++++ & ++++ & ++ & + & + & ++ & ++ & ++++ & +++ & +++++ \\
\hline
\end{tabular}

Note:- Staining Intensity : $++++=$ very intense reaction, $+++=$ Intense reaction, $++=$ Moderat reaction, $+=$ Less reactivity, $-=$ No reactivity.

Abberivations:- PAS $=$ Periodic Acid Schiff, $\mathrm{AB}=$ Alcian blue, $\mathrm{PH}=$ Phenyl Hydrazine $\mathrm{P}=$ Pink. OTAB $=$ optic tentacle ablated OTIN $=$ optic tentacle intact OTEI= Optic Tentacles Extract Injection. 
Table 2 : Effect of optic tentacle extract on polysaccharides In the albumen gland of semperula maculata*.

\begin{tabular}{|c|c|c|c|c|c|c|c|c|c|c|c|c|c|c|c|c|}
\hline \multirow{3}{*}{$\begin{array}{l}\text { Sr. } \\
\text { no. }\end{array}$} & \multirow{3}{*}{$\begin{array}{c}\text { Experiment-al } \\
\text { Methods }\end{array}$} & \multicolumn{15}{|c|}{ PERCENTAGE OF POLYSACCHARIDES** } \\
\hline & & \multicolumn{5}{|c|}{ GLYCOGEN } & \multicolumn{5}{|c|}{ GALACTOGEN } & \multicolumn{5}{|c|}{ TOTAL POLYSACCHARIDES } \\
\hline & & \multicolumn{5}{|c|}{ EXPERIMENTAL DAYS } & \multicolumn{5}{|c|}{ EXPERIMENTAL DAYS } & \multicolumn{5}{|c|}{ EXPERIMENTAL DAYS } \\
\hline & & 10 & 20 & 30 & 40 & 50 & 10 & 20 & 30 & 40 & 50 & 10 & 20 & 30 & 40 & 50 \\
\hline 1. & & 2.50 & 2.13 & 2.00 & 2.50 & 1.23 & 3.00 & 3.75 & 4.02 & 5.13 & 6.91 & 5.50 & 5.88 & 6.02 & 6.97 & 8.14 \\
\hline 2. & $\mathrm{C}$ & 1.34 & 1.02 & 0.97 & 0.62 & 0.44 & 1.52 & 2.47 & 2.32 & 2.81 & 3.35 & 2.86 & 3.49 & 3.29 & 3.43 & 3.75 \\
\hline 3. & OTAB+OTEI & 2.65 & 2.14 & 1.91 & 1.23 & 0.95 & 3.12 & 3.94 & 4.75 & 5.66 & 7.32 & 5.77 & 6.08 & 6.66 & 6.89 & 8.27 \\
\hline
\end{tabular}

N.B. * The percentage of glycogen and galactogen were estimated by Caroll et.al. (1956) method.

** The percentage of glycogen and galactogen are expressed as $\mathrm{mg} / 100 \mathrm{mg}$ of wet tissue.

OTAB $=$ optic tentacle ablated. OTIN $=$ optic tentacle intact. OTEI = Optic Tentacle Extract Injection.
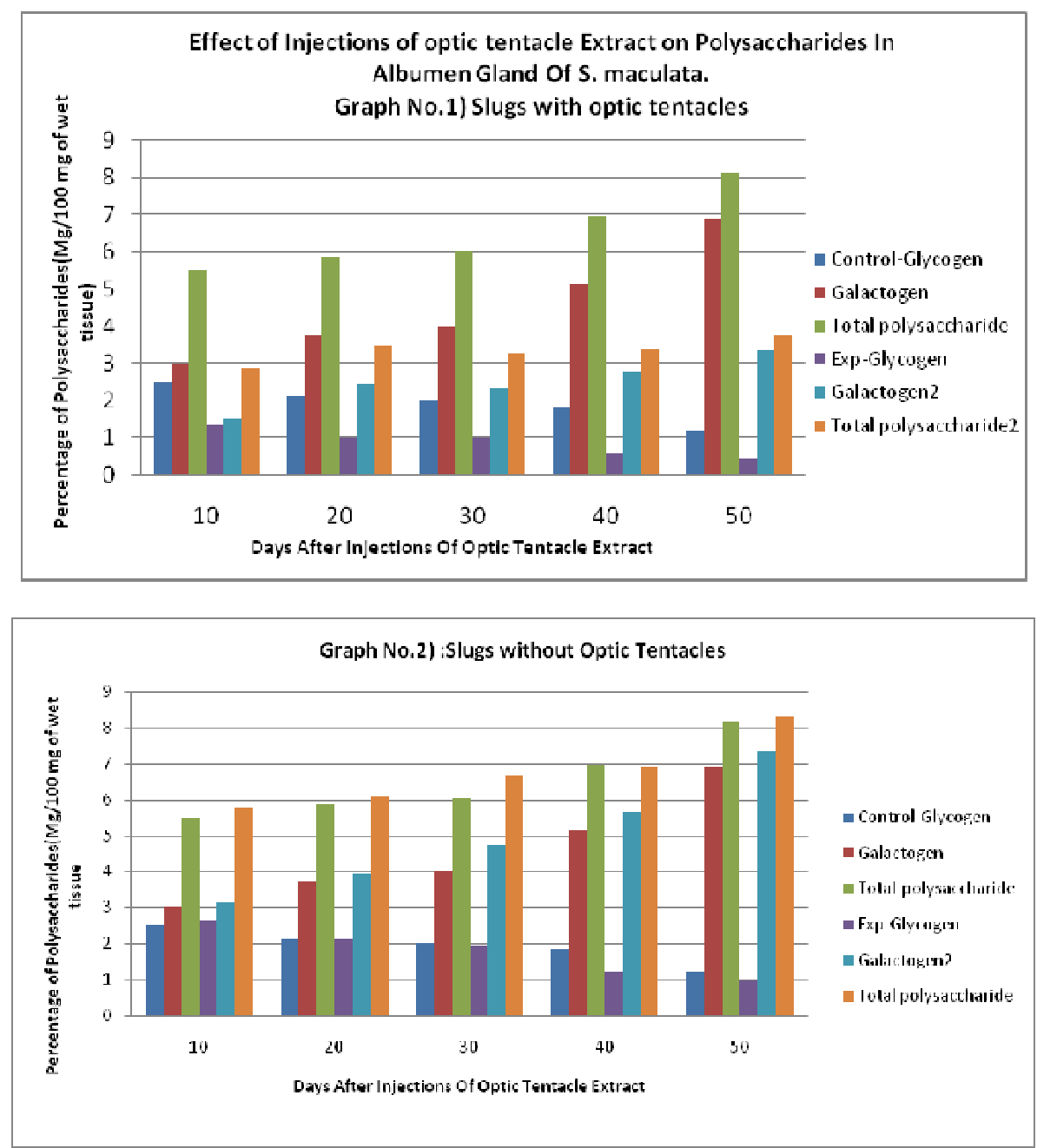

\section{Acknowledgement:}

I wish to thank principal Abhaykumar Salunkhe working president prin. Sou. Shubhangi Gavde, Secretary, Shri Swami Vivekanand Shikshan Sanstha, Kolhapur and principal DrA.N.Patil to create the facilities for the research work.

\section{References}

1.Abeloos M [1943] Effects de la castration chez un mollusque, Limax maximus L. C. V. Acad Sci Paris 216, 90-91.
2.Goudsmith E. M. [1972] Carbohydrates and carbohydrate metabolism in mollusecs. In Chemical Zoology [ Edited by Scheer B. T. and Florkin M.], vol. 7, pp. 219-243. Academic Press, New York.

3.Goudsmit E. M. [1975] Neurosecretory Stimulation of galactogen synthesis within the $\mathrm{H}$. pomatia gland during organ culture. J. Exp. Zool., 191, 193-198.

4.Goudsmit E. M. and Friedmant T. B. [1975] Enzymatic synthesis and interconversion of UDP-D-glucose and UDP-D-galactogen of the 


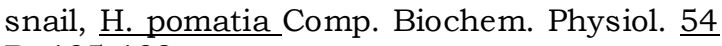
B, 135-139.

5.Goudsmit E. M. and Ashwell G. [1965] Enzymatic synthesis of galactogen in the snail, H. pomatia Biochem. Res. Commun. $\underline{19}$, 417-422.

6.Horstman N. H. J. [1956] Der galactogengehalt der Eier von $\underline{L}$. stagnalis wahrend der embryonalentwicklung. Biochem.Z.328,342-347.

7.Jooses J., M. H. Boer and C. H. Cornellisse [1968] Gametogenesis and oviposition in $\underline{L}$. stagnallis as influenced by irradiation and hunger. Symp Zool. Soc. Lond. 22, 213-235.

8. McMahon P., von Brand T. and Nolan M. O. [1957] Observation on the polysaccharides of aquatic snails. J. Cell. Comp. Physiol., 므, 219-240.

9.Laviolette P. [1954] role de la gonzde dans le determinism humeral de la maturile glandulaire du tractus genital chez quelques gasteropodes Arionidae et limacidae. Bull. Biol. Fr. Belg. 88, 310-332.

10. Miksys s. and Saleuddin A. S. M. [1985]. The effect of the brain and dorsal bodies of Helisoma duryi [mollusa, pulmonata] on albumen gland synthetic activity in vitro. Gen. Comp., Endocrinol. 60, 419-426.
11. Nieland, M. L. and Goudsmit E. M. [1969] Ultra structure of galactogen in the

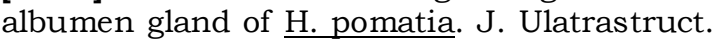
Res. 29, 119-140.

12. Runham N. W., Bailey T. G. and Lanjea A. A. [1973] Studies on the endocrine control of the reproductive tract of the grey field slug Agriolimax veticulatum. Macacologia. 14, 135-142.

13. Spicer S. S., Horn R. G. and Leppi T. J. [1957] In "The Connective Tissue", Int. Acad. Pathol. Monograph, $\underline{7}, 251-303$.

14. Varute A. T. and Nanaware S. G. [1972] Histochemical analysis of metachromasisa of galactogen: a confirmatory technique for histochemicl detection of galactogen. Folia Histochem. Cytochem 10, 37-46.

15. Wijdenes J. Eik R., Van and Joosse J. [1983] Effects of two gonadotropic hormones on polysaccharide synthesis in the albumen gland of L. stagnalis, studies with the organ culture technique. Gen. Comp. Indocrinol. $\underline{51}$, 263-271.

16. Yadav P.P. and Nanaware S.G.[2010] Studies on ultrastructural architecture of albumen gland cells in S.maculata. National Journal of Life Sciences, Vol.7(3), 65-66. 